\title{
Desain Etnik Yacht sebagai Sarana Wisata di Pulau Lombok
}

\author{
Yudhistira Ardhi Nugraha, dan Hasanudin \\ Departemen Teknik Perkapalan, Fakultas Teknologi Kelautan, Institut Teknologi Sepuluh Nopember \\ (ITS) \\ e-mail: hasanudinits@gmail.com
}

\begin{abstract}
Abstrak-Meningkatnya jumlah pengunjung baik domestik maupun mancanegara ke Pulau Lombok setiap tahunnya menunjukkan pulau ini masih memiliki potensi untuk terus dikembangkan pada sektor pariwisata. Menurut data dari Badan Pusat Statistik Lombok, jumlah wisatawan Pulau Lombok pada tahun 2016 mencapai 3.094.437 orang namun jumlah kapal yacht yang beroperasi hanya berjumlah 4 kapal. Kapal yang beroperasi pun masih impor dan tidak ada yang memakai interior etnik khas Lombok. Berdasarkan latar belakang tersebut, penulis melakukan penelitian mengenai Yacht Etnik yang sesuai dengan dengan karakteristik Pulau Lombok. Yacht Etnik direncanakan akan berlayar selama dua hari menuju Pulau Gili Nanggu, Pulau Gili Matra (Air, Meno, Trawangan) dan Pantai Senggigi. Penentuan ukuran utama awal kapal menggunakan 13 kapal pembanding dan presentase jumlah wisatawan bahari di Pulau Lombok sebagai acuan dalam penentuan payload kapal. Dari proses tersebut, ukuran utama yang didapatkan adalah $\mathrm{Lpp}=22,30 \mathrm{~m}, \mathrm{~B}=9,30 \mathrm{~m}, \mathrm{~T}=1,52 \mathrm{~m}$, $H=3,60 \mathrm{~m}, B_{1}=3,30 \mathrm{~m}, C_{B}=0,398$ dan $V_{s}=10$ knot dengan jumlah penumpang sebanyak 7 orang dan 3 crew. Sedangkan, Analisis Ekonomis dilakukan dengan Analisis Kelayakan Investasi. Kelayakan investasi dilakukan dengan biaya pembangunan = Rp. 4.781.883.554,94; NPV = Rp 1.160.290.152; IRR $=17 \%$; dan PP = 6,33 tahun.
\end{abstract}

Kata kunci-Etnik Yacht, Kapal Wisata, Pulau Lombok, Analisis Teknis dan Ekonomi.

\section{PENDAHULUAN}

I NDONESIA merupakan salah satu negara kepulauan terbesar dengan memiliki garis pantai $81.000 \mathrm{~km}$ dan mempunyai total luas terumbu karang sekitar $60.000 \mathrm{~km}^{2}$ yang terhampar dari ujung barat sampai ujung timur wilayah laut Indonesia, dan Indonesia merupakan rumah dari 1/8 dari jenis terumbu karang yang ada di dunia. Dari data dan fakta laut Indonesia dapat menjadi nilai jual tersendiri untuk dijadikan alat untuk menarik wisatawan lokal maupun asing untuk berwisata di wilayah laut Indonesia [1].

Pariwisata Lombok bukan hanya mengandalkan Gunung Rinjani tapi juga sejumlah pantai yang terbentang disepanjang pulau Lombok. Kawasan pantai sudah dilengkapi berbagai fasilitas seperti penginapan, tempat hiburan, hingga pasar seni yang menjual aneka barang seni produk lokal. Banyak wisatawan mancanegara terpesona oleh wisata lombok, selain pantainya yang berombak tenang dengan panorama yang indah, juga karena keindahan taman laut di Lombok. Keindahan wisata di Lombok selain di pantai Senggigi adalah kawanan pulau kecil yang terdiri dari Gili Air, Gili Meno, Gili
Trawangan, pulau-pulau kecil ini terletak di sebelah barat laut pulau Lombok. Wisata yang ditawarkan di Pulau Lombok sangat beragam, wisata laut berupa snorkling dan spot diving yang menarik untuk dicoba. Selain itu juga terdapat 3 Gili yaitu Gili Trawangan, Gili Meno dan Gili Air masih mendominasi untuk dijadikan tempat diving dan snorkeling atau sekedar bersantai di tepian pantai.

Dengan jumlah pengunjung yang selalu meningkat maka membuktikan bahwa daya tarik di pulau ini semakin meningkat pula. Maka sudah selayaknya pemerintah setempat atau organisasi terkait mulai mensiasati pola perkembangan ini dengan cara berkaca dari negara negara yang sudah maju dalam mengelola pariwisata bahari. Sebagian besar Kapal Yacht yang ada pada saat ini di Pulau Lombok masih membeli dari luar negeri. Sehingga desain interiornya pun masih sama dengan etnik budaya dari negara lain.

Dengan permasalahan yang ada seperti diatas, maka penulis melakukan studi desain Kapal Yacht yang mampu menjadi solusi kebutuhan wisatawan di Pulau Lombok. Selain berfungsi sebagai sarana pariwisata, kapal ini menggunakan desain interior etnik khas Pulau Lombok sehingga wisatawan terasa lebih nyaman dan mengenal budaya khas Pulau Lombok.

\section{TINJAUAN PUSTAKA}

\section{A. Pulau Lombok}

Pulau Lombok termasuk kedalam gugusan kepulauan Sunda Kecil yang pecah setelah kemerdekaan Republik Indonesia. Pulau ini masuk kedalam kepulauan Nusa Tenggara dan secara geografis hanya dipisahkan oleh Selat Lombok dengan Pulau Bali. Pulau ini termasuk kedalam provinsi Nusa Tenggara Barat dan merupakan pulau terbesar di kepulauan Nusa Tenggara Barat. Ibukota provinsi terletak di pulau ini, sehingga dipulau inilah aktifitas padat bisa didapatkan.

Pulau ini berbentuk menyerupai bulat dengan semacam "ekor" di sisi barat daya yang panjangnya kurang lebih $70 \mathrm{~km}$. Luas pulau ini mencapai $5.435 \mathrm{~km}^{2}$, menempatkannya pada peringkat 108 dari daftar pulau berdasarkan luasnya di dunia. Kota utama di pulau ini adalah Kota Mataram. Pulau Lombok juga memiliki sejuta pesona alam yang menakjubkan. Pemandangan yang masih asri dan tradisi setempat yang unik menjadi daya tarik pulau ini. Setidaknya satu setengah juta orang dating ke pulau ini setiap tahunnya. Berdasarkan data yang didapatkan dari dinas pariwisata Nusa Tenggara Barat, mayoritas wisatawan asing yang datang berkunjung ke Lombok adalah dari Perancis, Belanda dan Australia [2]. 


\section{B. Katamaran}

Katamaran adalah kapal dengan lambung ganda atau twinhulls. Kedua lambung katamaran dihubungkan dengan struktur bridging, yaitu struktur geladak diantara kedua lambung yang digunakan untuk memberikan kekuatan melintang pada kapal. Keuntungan katamaran dibandingkan dengan kapal monohull adalah geladak kapal lebih luas, memiliki stabilitas yang lebih baik, lebih nyaman karena sudut oleng lebih kecil. Namun terdapat beberapa kekurangan, seperti teori tentang perhitungan yang masih kurang, pembuatan kapal lebih rumit, dan kemampuan maneuver kurang baik [3].

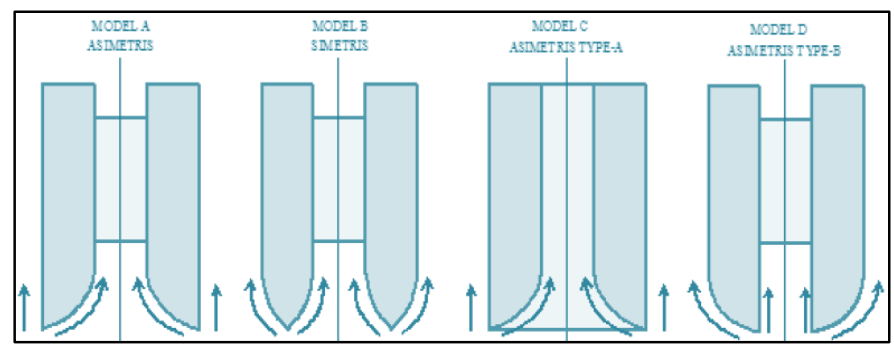

Gambar 1. Jenis Lambung Katamaran

Seperti yang terlihat pada Gambar 1, terdapat tiga jenis lambung katamaran, yaitu simetris, asimetris dengan bagian dalam lurus dan asimetris dengan bagian luar lurus. Sedangkan bentuk lambungnya dibedakan menjadi tiga jenis, yaitu Round Bilge, Hard Chine, dan Wave Piercing [4][5].

\section{Yacht}

Yacht awalnya didefinisikan sebagai kapal layar ringan dan cepat yang digunakan untuk mengantar orang penting. Dalam perkembangan berikutnya, definisi berubah menjadi suatu kapal, selain dinghy, yang didorong oleh layar dan digunakan untuk pelayaran hobi dan/atau balap yacht dengan tujuan awal digunakan untuk memancing. Yacht memiliki panjang yang bervariasi mulai dari $6 \mathrm{~m}$ (20 kaki) sampai $30 \mathrm{~m}$ (98 kaki) atau lebih. Namun, kebanyakan yacht pribadi memiliki panjang sekitar $7 \mathrm{~m}$ hingga $14 \mathrm{~m}$. Seperti yang terlihat pada Gambar 2 bersumber dari sunreefyacht.com, bahwa kapal pesiar memang kapal penumpang. Namun yang menjadi pembedanya dengan kapal penumpang lainnya, adalah penumpang kapal pesiar biasanya berlayar untuk menghabiskan waktu luang sambil menikmati berbagai fasilitas di atas kapal. Karenanya kapal pesiar dilengkapi dengan fasilitas layaknya di hotel [6].

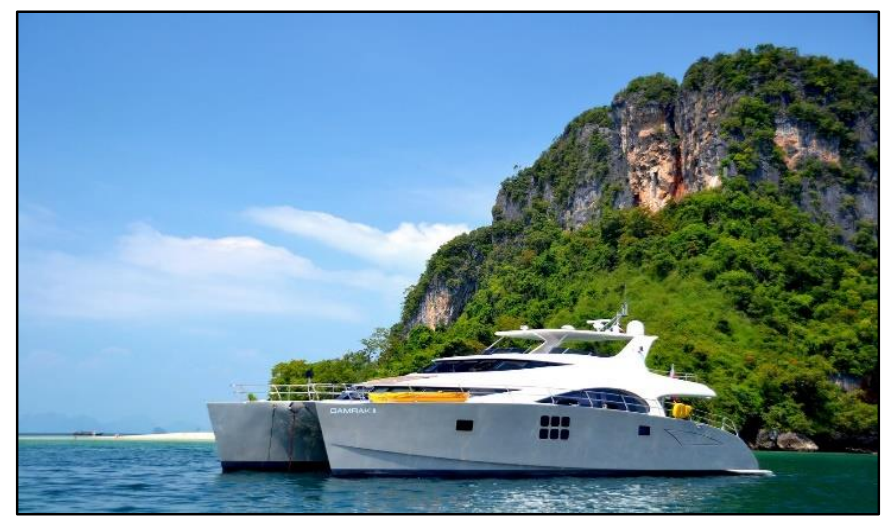

Gambar 2. Sunreef Yacht 70

\section{Pendekatan Desain}

Dalam proses desain kapal dibutuhkan proses yang berulang-ulang untuk mendapatkan hasil optimal dengan cara mengatur dan menyeimbangkan parameter-parameter yang terkait dan diilustrasikan dalam Spiral Design. Di dalam diagram spiral design terdapat empat pembagian proses yaitu concept design, preliminary design, contract design, dan detail design [7][8].

\section{METODOLOGI PENELITIAN}

Secara umum prosedur pengerjaan penelitian ini dilakukan dengan langkah sesuai dengan diagram alir penelitian pada Gambar 3.

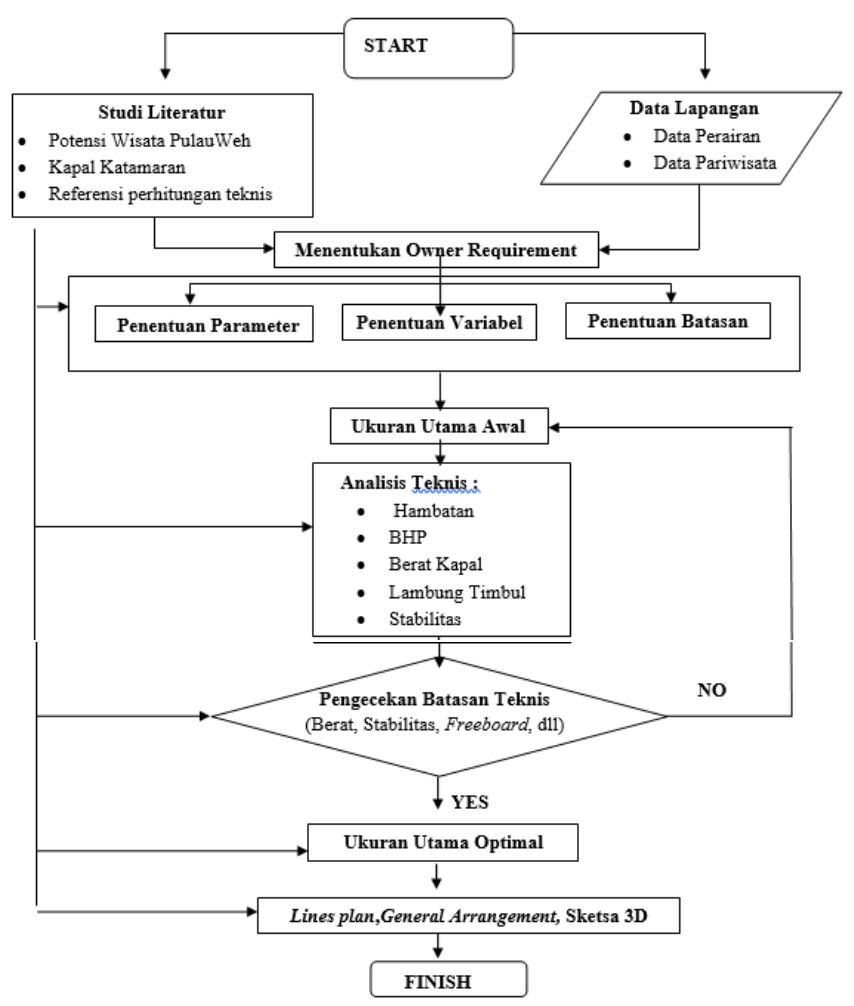

Gambar 3. Diagram Alir Pengerjaan

\section{* Studi Literatur}

Tahap pertama yang dilakukan adalah studi literatur, yaitu mengumpulkan teori-teori yang berkaitan dalam penyelesaian Studi.

* Tahap Pengumpulan Data

Data yang dimaksud yaitu data yang relevan dan mencakup segala aspek yang berhubungan dalam pengerjaan Studi.

\section{* Pengolahan Data}

Tahap-tahap pengolahan yang harus dilakukan; menentukan payload, menentukan rute kapal, menentukan kecepatan dinas, dan menentukan ukuran utama.

\section{* Perhitungan Teknis dan Ekonomis}

Perhitungan pada tahap ini meliputi; perhitungan hambatan, perhitungan propulsi, perhitungan berat dan titik berat, perhitungan stabilitas, perhitungan trim. Perhitungan 
ekonomis digunakan untuk memastikan kelayakan produksi dari kapal yang didesain.

* Pembuatan Rencana Garis dan Rencana Umum

Proses pembuatan rencana garis, dimana kelengkungankelengkungan dari bentuk badan kapal dapat dilihat. Desain rencana umum, yaitu gambar lengkap dari kapal yang didesain secara menyeluruh dari pandangan atas dan pandangan samping kapal.

* Pembuatan 3D

Gambar desain 3D ini digunakan untuk memberikan penjelasan secara lebih riil dari desain rencana umum.

* Kesimpulan dan Saran

Kesimpulan berupa jawaban atas tujuan dari studi. Sedangkan saran berisi tentang hal-hal yang dapat dikembangkan dari Studi yang sedang dikerjakan.

\section{ANALISIS TEKNIS}

Kapal wisata didesain supaya wisatawan bisa menikmati wisatanya dengan maksimal. Itu bisa dicapai dengan cara memberikan fasilitas - fasilitas yang menyenangkan, dengan tetap memperhatikan faktor kenyamanan dan keamanan. Selain itu, biaya pembangunan dan operasional juga diperhitungkan untuk mendapatkan keuntungan. Maka, perlu dilakukan penghitungan teknis serta analisis ekonomis kapal.

\section{A. Penentuan Payload}

Penentuan payload kapal yang didesain mengacu pada data jumlah kunjungan wisatawan dan data jumlah kapal yang beroperasi di Pulau Lombok. Kedua data tersebut digunakan untuk mendapatkan data kebutuhan kapal wisata pada tahun 2017. Jumlah kunjungan wisata pada tahun 2017 didapatkan dengan metode regresi linier dari jumlah kunjungan wisata pada tahun 2008 - 2016, seperti yang terlihat pada

Gambar 4 merujuk pada Dinas Pariwisata Lombok.

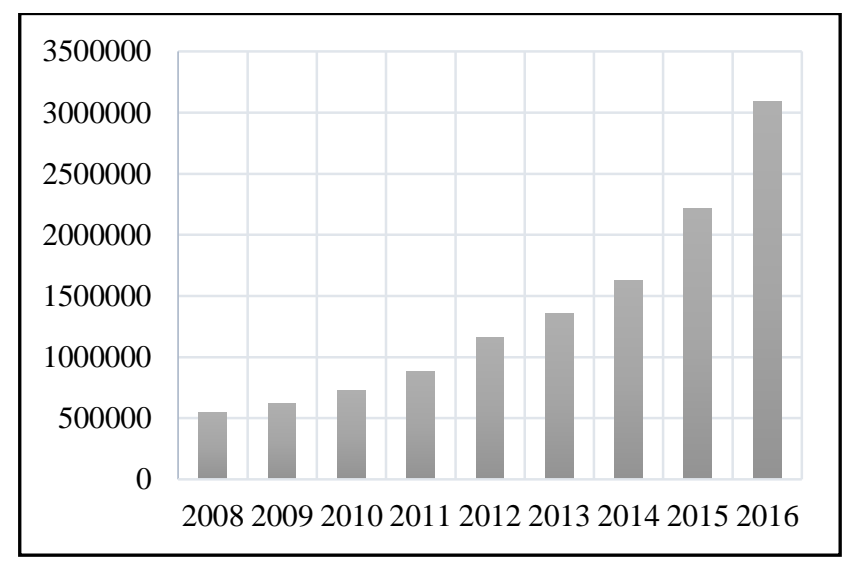

Gambar 4. Peningkatan Jumlah Kunjungan Wisata di Lombok
Tabel 1

Kunjungan wisata pada tahun 2017

\begin{tabular}{llcc}
\hline \hline \multicolumn{1}{c}{ Ukuran Utama Kapal } & & & \\
\hline Length of Perpendicular $(\mathrm{Lpp})$ & $=$ & 22,30 & $\mathrm{~m}$ \\
Breadth Moulded $(\mathrm{B})$ & $=$ & 9,30 & $\mathrm{~m}$ \\
Breadth of Demihull $\left(\mathrm{B}_{1}\right)$ & $=$ & 3,30 & $\mathrm{~m}$ \\
Height Moulded $(\mathrm{H})$ & $=$ & 3,60 & $\mathrm{~m}$ \\
Draft Moulded $(\mathrm{T})$ & $=$ & 1,52 & $\mathrm{~m}$ \\
Velocity Service $\left(\mathrm{V}_{\mathrm{S}}\right)$ & $=$ & 10 & Knot \\
Distance Separation of Demihull & $=$ & 6,00 & $\mathrm{~m}$ \\
$(\mathrm{~S})$ & &
\end{tabular}

Berdasarkan hasil regresi didapatkan jumlah kunjungan wisata pada tahun 2017 sebesar 2.516 .908 orang. Menurut data dari Dinas Pariwisata Lombok sebanyak 5\% dari total wisatawan merupakan wisatawan bahari yang menyewa yacht. Sehingga jumlah wisatawan yang menyewa yacht pada tahun 2017 sebanyak 207 orang setiap harinya. Namun sayangnya jumlah peningkatan kunjungan wisatawan ini tidak diimbangi dengan tersedianya yacht yang beroperasi, seperti yang terlihat dari Tabel .

Tabel 2.

Data Yacht di Lombok

\begin{tabular}{ccccc}
\hline \hline Kapal & $\begin{array}{c}\text { Jumlah } \\
\text { Penumpang }\end{array}$ & KT & KM & Kasur \\
\hline PIRATES & 12 & 4 & 1.5 & 5 \\
Kapal B & 8 & 3 & 2 & 6 \\
CATAMARAN & 6 & 2 & 1 & 2 \\
BIG KANU & 11 & 9 & 1 & 11 \\
\hline \hline
\end{tabular}

Dari kedua data diperoleh selisih antara jumlah kunjungan wisatawan pada tahun 2017 dengan jumlah kapal yang dapat mengakomodasi wisatawan sebesar 170 orang. Selisih tersebut tidak dapat dijadikan payload secara langsung karena faktor kenyamanan dan keselamatan penumpang.

\section{B. Penentuan Rute Kapal}

Berdasarkan hasil tinjauan daerah yang sudah dilakukan pada perairan di Pulau Lombok, didapatkan potensi yang bisa dikembangkan pada tiga lokasi yaitu di Pulau Gili Nanggu, Pulau Gili Matra dan Pantai Senggigi. Hal ini didasari karena karena kekayaan bawah laut lokasi tersebut masih terjaga dan bagus sehingga sangat cocok untuk dijadikan destinasi diving maupun snorkeling. Berdasarkan data tersebut maka penulis membuat rute pelayaran seperti terlihat pada Gambar 5. dengan menggunakan referensi web Navionic[9].

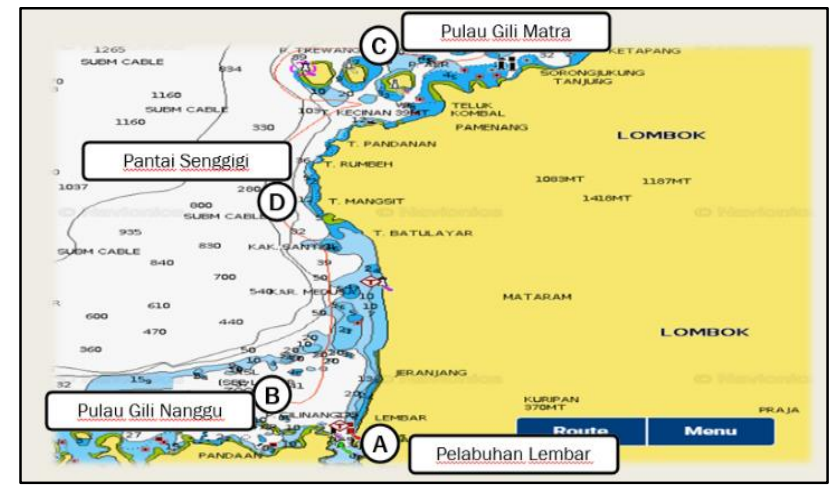

Gambar 5. Rute Pelayaran 


\section{Penentuan Ukuran Utama}

Dalam penentuan ukuran utama awal, digunakan 13 kapal pembading. Selanjutnya, dilakukan regresi linier ukuran utama awal yang diperoleh dapat dilihat pada Error! Reference source not found. dan dan dibandingkan dalam rentang rasio yang mengacu pada paper M. Insel dan A. F Moland, seperti yang terlihat pada Tabel 2 [9].

\section{Perhitungan Hambatan}

Perhitungan hambatan total dilakukan dengan metode yang didapat dari paper M. Insel dan A.f. Molland [10]. Formula dalam metode tersebut adalah :

$$
\begin{aligned}
& \mathrm{R}_{\text {tot }}=0,5 \times \rho \times \text { WSA } \times V^{2} \times 2 \mathrm{C}_{\text {tot }} \\
& \mathrm{R}_{\text {tot }}=11,981 \mathrm{kN}
\end{aligned}
$$

Setelah didapatkan nilai $\mathrm{R}_{\text {tot }}$ maka dilanjutkan dengan perhitungan EHP kemudian DHP kapal. Selanjutnya dilakukan penambahan koreksi 15\% terhadap DHP dan didapatkan BHP yaitu $143.150 \mathrm{~kW}$. Nilai BHP ini digunakan untuk menentukan mesin induk dan generator set.

\section{E. Perhitungan Berat Kapal}

Pada perhitungan berat kapal Etnik Yacht ini, ada dua kelompok utama yang dihitung yaitu LWT (Light Weight Tonnage) dan DWT (Dead Weight Tonnage) seperti terlihat pada

Tabel 1 dan Tabel 2.

Tabel 1.

\begin{tabular}{|c|c|c|c|}
\hline \multicolumn{4}{|c|}{ Light Weight } \\
\hline No. & Macam-Macam Berat & Jumlah & Satuan \\
\hline \multicolumn{4}{|c|}{ Permesinan ; } \\
\hline 1 & Mesin Induk & 1,534 & ton \\
\hline 2 & Generator & 1,380 & ton \\
\hline \multicolumn{4}{|c|}{ Perlengkapan ; } \\
\hline & & 7,246 & ton \\
\hline \multicolumn{4}{|c|}{ Konstruksi ; } \\
\hline 1 & Alas & 3,503 & ton \\
\hline 2 & Lambung & 2,874 & ton \\
\hline 3 & Geladak & 3,672 & ton \\
\hline 4 & Bangunan Atas & 4,470 & ton \\
\hline 5 & Estimasi Konstruksi Kapal & 3,630 & ton \\
\hline \multirow[t]{2}{*}{6} & Railing & 1,218 & ton \\
\hline & Subtotal & 29,526 & ton \\
\hline
\end{tabular}

Rekapitulasi Berat LWT Kapal

Tabel 2.

Rekapitulasi Berat DWT Kapal

\begin{tabular}{cccc}
\hline \hline \multicolumn{4}{c}{ Dead Weigth } \\
\hline No. & Macam-Macam Berat & Jumlah & Satuan \\
1 & Berat Bahan Bakar & 0,080 & ton \\
\hline \hline
\end{tabular}

\begin{tabular}{cccc}
\hline \hline 2 & Berat Minyak Lumas & 0,003 & ton \\
3 & Berat Air Tawar & 1,013 & ton \\
4 & Berat Penumpang \& Bawaan & 0,735 & ton \\
5 & Berat Kru dan Barang Bawaan & 0,255 & ton \\
& Subtotal & $\mathbf{2 , 0 8 5}$ & ton \\
\hline \hline
\end{tabular}

Berdasarkan hasil reapitulasi LWT dan DWT diatas, kemudian dilakukan koreksi terhadap displacement.

$$
\begin{aligned}
\text { Correction } & =\boldsymbol{\Delta}-(\mathbf{L W T}+\mathbf{D W T}) \\
& =0,044 \text { ton }(0,140 \%)
\end{aligned}
$$

Nilai displacement kapal yang lebih besar daripada jumlah LWT dan DWT. Hal ini menunjukkan bahwa gaya angkat kapal lebih besar dan kapal dapat mengapung.

\section{F. Perhitungan Trim Kapal}

Trim adalah selisih antara LCB dan LCG. Batasan trim didasarkan pada selisih keduanya dengan batasan lebih kecil atau sama dengan $0,1 \% \times$ LWL. Pada penelitian ini, trim dihitung berdasarkan metode Parametric Design, Chapter 11 [11].

$$
\begin{aligned}
\text { Trim } & =(\mathrm{LCG}-\mathrm{LCB}) \times(\mathrm{L} / \mathrm{GML}) \\
& =0,058 \mathrm{~m} \\
\text { Batasan Trim } & =0,5 \% \times \mathrm{LWL} \\
& =0,111 \mathrm{~m}
\end{aligned}
$$

Berdasarkan data diatas, nilai trim adalah postif maka kapal dalam kondisi trim buritan dan model memenuhi persyaratan karena tidak melebihi batasan trim.

\section{G. Perhitungan Freeboard}

Perhitungan Freeboard mengacu pada "International Convention of Load Lines, 1966, Protocol of 1988" dan pada aturan "Non-Covention Vessel Standard Indonesia Flaged Chapter IV"[12][13]. Kapal Etnik Yacht ini termasuk kapal Tipe B. Pada perhitungan freeboard, terdapat beberapa koreksi antara lain koreksi koreksi depth dan koreksi freeboard kapal dibawah $100 \mathrm{~m}$. Nilai freeboard desain adalah 2,08 m sedangkan nilai freeboard minimal adalah $0,60 \mathrm{~m}$ sehingga freeboard desain sudah memenuhi persyaratan.

\section{H. Perhitungan Stabilitas}

Pada penelitian ini, perhitungan stabilitas kapal menggunakan metode kyrlov dengan bantuan software. Criteria yang digunakan adalah Intact Stability (IS) Marine Guidance Note (MGN) 280 Chapter 11 section 3.7. Stabilitas harus di analisis terhadap banyak kondisi karena pada

\begin{tabular}{|c|c|c|c|c|c|c|}
\hline \multirow{2}{*}{ No } & \multirow{2}{*}{ Kriteria } & \multirow{2}{*}{ Unit } & \multicolumn{3}{|c|}{ Loadcase } & \multirow{2}{*}{ Kondisi } \\
\hline & & & 1 & 2 & 3 & \\
\hline
\end{tabular}
kenyataanya kapal banyak menghadapi banyak kondisi seperti kondisi muatan penuh, kondisi tangki setengah penuh dan kondisi tangka teriai 10\%. Berdasarkan analisis maka didapatkan data pada

Tabel 3

Tabel 3.

Hasil Analisis Stabilitas 


\begin{tabular}{ccccccc}
\hline \hline 1 & $\mathrm{~A} \theta_{(20)} \geq 0,075$ & m.deg & 25,84 & 14,13 & 14,14 & Accepted \\
2 & $\mathrm{~A} \theta_{(30-40)} \geq 1,719$ & m.deg & 35,34 & 37,47 & 37,99 & Accepted \\
3 & $\mathrm{GZ}_{30} \geq 0,2$ & $\mathrm{~m} \cdot \mathrm{deg}$ & 1,704 & 1,94 & 1,92 & Accepted \\
4 & $\theta \mathrm{GZ}_{\max } \geq 15^{\circ}$ & $\mathrm{m}$ & $20^{\circ}$ & $20^{\circ}$ & $20^{\circ}$ & Accepted \\
5 & $\mathrm{GM} \geq 0,35$ & $\mathrm{deg}$ & 9,58 & 8,63 & 8,92 & Accepted \\
\hline \hline
\end{tabular}

\section{Lines Plan \& General Arrangement}

Berdasarkan ukuran utama kapal, kemudian dibuat model lambung kapal menggunakan software sesuai dengan koefisien dan data hidrostatik pada perhitungan. Hasil desain kemudian di tampilkan kedalam 3 pandangan; body plan, sheer plan dan halfbreadth plan yang selanjutnya diedit menggunakan software sehingga didapatkan hasil akhir seperti pada Gambar 6.

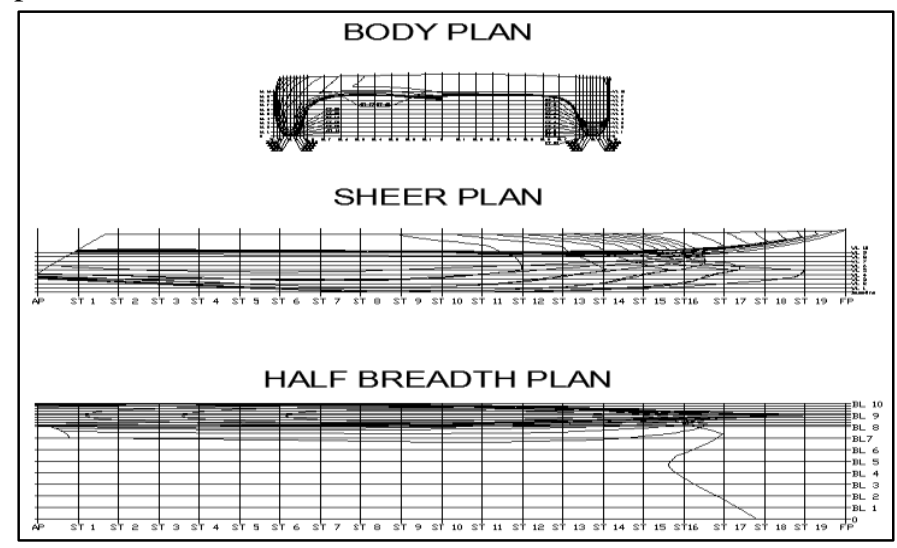

Gambar 6. LinesPlan Glass Bottom Catamaran Boat

General Arrangement digunakan untuk merencanakan ruangan yang dibutuhkan sesuai dengan fungsi dan perlengkapan kapal. Desain dilakukan menggunakan software desain dengan memperhatikan penataan geladak supaya mampu mengakomodasi seluruh penumpang, nyaman, memiliki estetika yang tinggi serta sesuai dengan konsep yang diusung. Peletakan peralatan dan perabotan juga harus diperhatikan karena berpengaruh dengan perhitungan titik berat kapal. Hasil desain general arrangement ada pada Gambar 7.

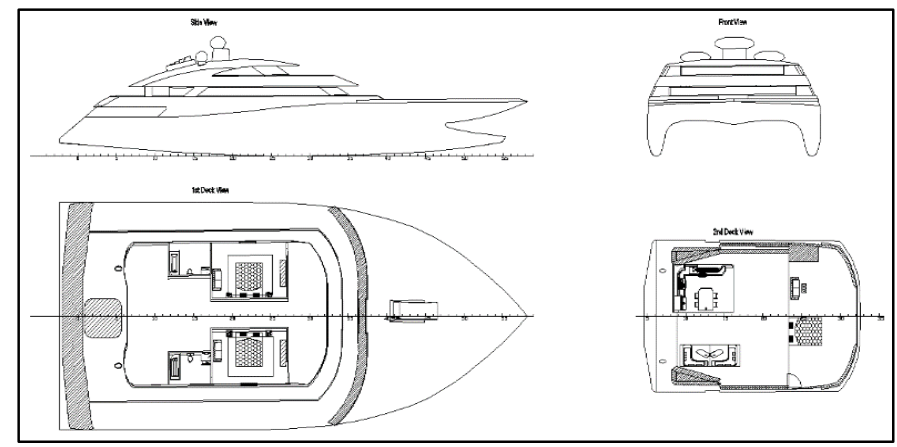

Gambar 7. General Arrangement Glass Bottom Cataaran Boat

\section{J. Desain Tiga Dimensi}

Dari desain General Arrangement yang sudah ada kemudian dilanjutkan dengan pembuatan desain interior tiga dimensi. Tujuan dari pembuatan desain ini adalah untuk memudahkan dalam memvisualisasikan bentuk dari Ethnic Yacht ini. Desain dilakukan menggunakan software dengan hasil seperti pada:

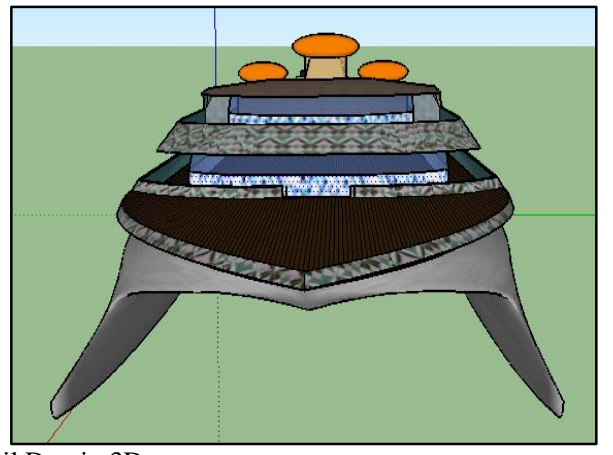

Gambar 8. Hasil Desain 3D

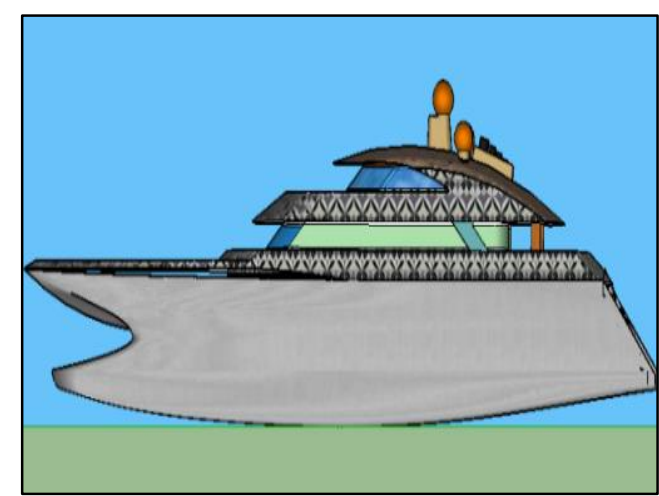

Gambar 9. Tampak samping

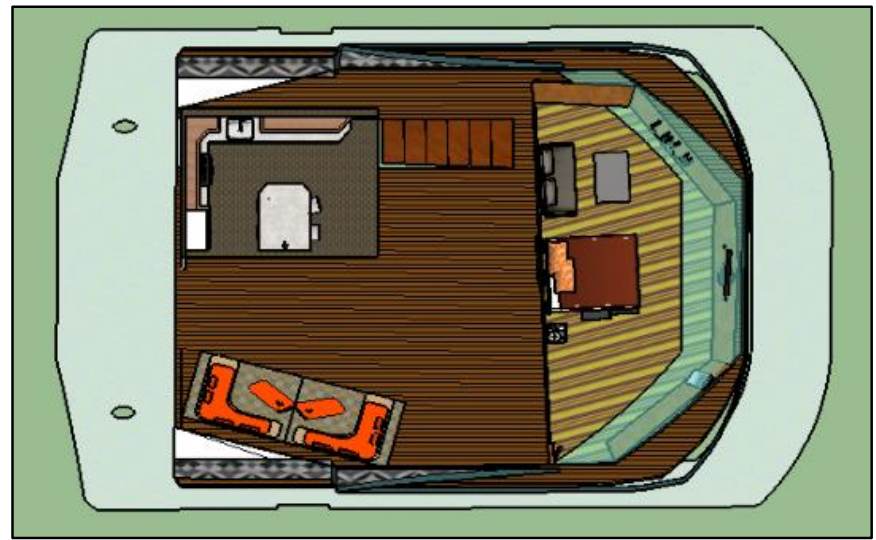

Gambar 10. Interior di 2nd Deck

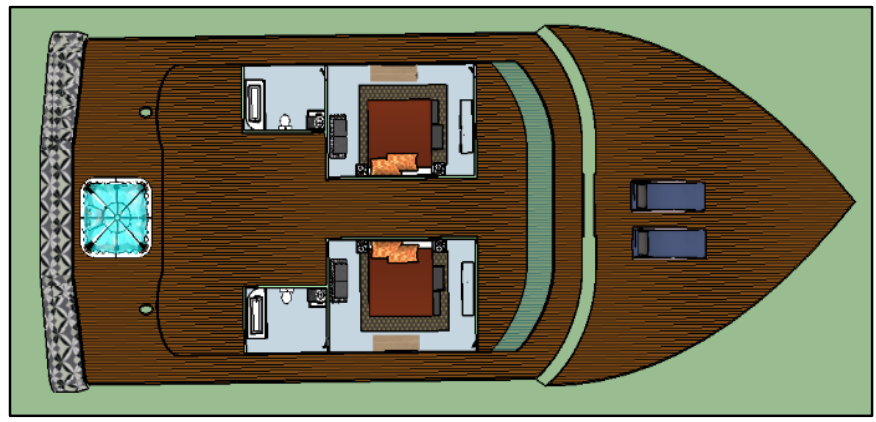




\section{Gambar 11. Interior di 1st Deck}

\section{K. Analisis Keekonomian}

Perhitungan keekonomian kapal ini bertujuan untuk mengetahui kelayakan investasi kapal berdasarkan perhitungan pemasukan dan pengeluaran.

$$
\begin{array}{ll}
\text { Building cost } & =\mathrm{Rp} 4.781 .883 .554,94 \\
\text { Operational cost } & =\mathrm{Rp} 2.512 .800 .152,92 \\
\text { NPV } & =\mathrm{Rp} 1.160 .290 .152 \\
\text { Payback rate } & =6,33 \text { tahun }
\end{array}
$$

\section{KESIMPULAN}

Dari seluruh pembahasan yang sudah dipaparkan pada beberapa bab sebelumnya, maka dapat ditarik kesimpulan sebagi berikut :

1. Dari hasil analisis teknis dan ekonomis, maka jumlah penumpang yang dapat diangkut adalah 7 orang dan $3 \mathrm{kru}$ kapal.

2. Hasil desain Kapal Etnik Yacht berupa Lines Plan, General Arrangement, Safety Plan, dan 3D Etnik. Sedangkan ukuran utama kapal yang digunakan adalah sebagai berikut;

- Length Overall (Loa) : 22,30 meter

- Length of Peendicular (Lpp) : 22,30 meter

- Length of Waterline (Lwl) : 22,30 meter

- Breadth Moulded $\left(\mathrm{B}_{\mathrm{M}}\right)$ : 9,30 meter

- Breadth of Demihull $\left(\mathrm{B}_{1}\right)$ : 3,30 meter

- Draught (T) : 1,52 meter

- Depth (D) : 3,60 meter

- Block Coefficient $\left(\mathrm{C}_{\mathrm{B}}\right)$ : 0,398
3. Dari hasil analisis kelayakan investasi terkait perencanaan wisata, didapat hasil sebagai berikut;

- Building Cost

- Loan from bank

: Rp 4.781.883.554,94

- Loan Duration

: Rp 3.108.224.310,71

- Discount Rate from bank : :13,5\%

- Net Present Value

: Rp 1.160.290.152

- Internal Rate of Return : $\quad: 17 \%$

- Payback Period : 6,33 Tahun

\section{DAFTAR PUSTAKA}

[1] Wikipedia, "Pulau-Lombok," wikipedia, 2017.

[2] T. Rismayadi, "Aktivitas Promosi Dinas Pariwisata Dan Kebudayaan Kabupaten Lombok Barat dalam Meningkatkan Jumlah Kunjungan Wisata," 2016.

[3] I. Bashori, "Perancanaan Awal Sightseeing-Catamaran Bertenaga Surya untuk Perairan Paciran Lamogan,” ITS, 2013.

[4] E. Darmawan, "Studi Perancangan Glass Bottom Catamaran Untuk Menunjang Objek Wisata Di Kawasan Anak Gunung Krakatau," UNDIP, 2012.

[5] R. . Hutama, "Desain Self-Prpopelled Resort untuk Wisata Bahari di Perairan Bali - Lombok," 2016.

[6] Planetkapal.com, "Planetkapal.com," 2017. [Online]. Available: Planetkapal.com.

[7] D. Watson, "Practical Ship Design," Elsevier, vol. 1, 19998.

[8] A. . Aryansyah, "Desain Glass Bottom Catamaran Boat sebagai Sarana Wisata di Pulau Weh, Sabang," 2017.

[9] Navionic, "Navionic," 2017. [Online]. Available: http//Navionic.com.

[10] A. F. Molland, M., \& Insel, An Investigation Into the Resistance Components of High Speed Displacement Catamarans. RINA, 1992.

[11] M. G. Parsons, Chapter 11, Parametric Design. Univ. of Michigan, 2011.

[12] IACS, Interpretations of the International Convention on Load Lines. 2016.

[13] K. Perhubungan, Standar Kapal Non Konvensi Berbendera Indonesia Bab VI. 2009. 